\title{
Two new subfossil species of springsnails (Hydrobiidae: Pyrgulopsis) from North Mexico and their relation with extant species from Cuatrociénegas
}

\author{
Alexander Czaja, José Luis Estrada-Rodríguez, Ulises Romero-Méndez, Anselmo Orona-Espino
}

Alexander Czaja

José Luis Estrada-Rodríguez

drilestrada@ujed.mx

Ulises Romero-Méndez

Anselmo Orona-Espino

Facultad de Ciencias Biológicas, Universidad Juárez del Estado de Durango, 35010 Gómez Palacio, Durango, México.
BOL. SOC. GEOL. MEX. 2017

VOL. 69 NO. 1

P. $199-208$

\begin{abstract}
We describe two new species of the genus Pyrgulopsis Call and Pilsbry from subfossil spring deposits of Viesca, Coahuila, in the northern part of Mexico. The first species, $P . p a^{-}$ leominckleyi sp. nov., has trochiform shells with flat whorls and bulbous shoulders. Extant endemic species Pyrgulopsis minckleyi (Taylor) displayssimilar shell features — this species was originally described as Nymphophilus minckleyi Taylor from the spring complex of the Cuatrociénegas valley, Coahuila. Some specimens of $P$. paleominckleyi sp. nov. show wing-like shoulders that have never been observed among fossil or extant members of the genus. In addition, shells of the second new species from $\mathrm{Vi}$ esca, $P$. paleoacarinatus are similar to $P$. acarinatus, which is other endemic Pyrgulopsis species from Cuatrociénegas. We suppose that both sub-fossil springsnails of Viesca are sister species or, likely, direct precursors of the two extant endemic springsnails from Cuatrociénegas valley.
\end{abstract}

Keywords: Pyrgulopsis, new species, sub-fossil, North Mexico, Viesca, Cuatrociénegas.

\section{RESUMEN}

Se describen dos nuevas especies del género Pyrgulopsis Call and Pilsbry de depósitos subfósiles de Viesca, Coahuila, norte de México. La primera especie, $\underline{\text { P. paleominc- }}$ kleyi sp. nov., tiene conchas trochiformes con vueltas planas y hombros bulbosos. Conchas con características similares posee la especie endémica Pyrgulopsis minckleyi (Taylor), originalmente descrita como Nymphophilus minckleyi Taylor del complejo de pozas del valle de Cuatrociénegas, Coahuila. Algunos especimenes de P. paleominckleyi sp. nov. tienen hombros en forma de alas, características que nunca fueron observadas entre los miembros fósiles o recientes del género. Asimismo, las conchas de la segunda especie de Viesca, P. paleoacarinatus sp. nov. son muy similares a $\underline{P}$ acarinatus, otra especie endémica de Pyrgulopsis de Cuatrociénegas. Suponemos que los caracoles subfósiles de Viesca son especies hermanas o, más probable, precursores directos de dos caracoles de manantial recientes y endémicos del valle de Cuatrociénegas.

Palabras clave: Pyrgulopsis, especies nuevas, subfósil, Norte de México, Viesca, Cuatrociénegas. 


\section{Introduction}

Pyrgulopsis, commonly known as springsnail, is the most diverse genus of North American freshwater gastropods and contains approximately 140 described species (Hershler et al., 2014; 2016). The members of this genus live mostly in springs and have a very small geographic distribution (Hershler and Sada, 2002). Many of the species in western North America, particularly at the Great Basin in the northern of Mexico, they are endemic and restricted to small areas or to a single spring. Hershler et al. (2014) mentioned that members of the genus prefer emergent macrophytes and hard substrates as habitat.

The oldest occurrence of Pyrgulopsis dates back to the Pliocene (Henderson, 1935) but there is molecular evidence that shows the genus colonized the region of the Lower Colorado River in the late Miocene (Hurt, 2004). There are still no reliable records of fossil Pyrgulopsis shells from Mexico. Two shells described by Czaja et al. (2014a, Figures e and f) as Pyrgulopsis sp. from Late Quaternary Paleo-Lake Irritilian Coahuila do not belong to this genus but to the sister genus Cincinnatia Pilsbry, 1891. The only Late Holocene record of Pyrgulopsis, P. manantiali (Hershler), was recently described by Czaja et al. (2014b).

In sediments of two recently dried-up springs near the town of Viesca, Coahuila, specimens of two species of the genus Pyrgulopsis Call and Pilsbry, 1886 were collected. These shells have morphological similarities with shells of two endemic extant species of Pyrgulopsis from Cuatrociénegas, Coahuila-originally assigned to the genus $\mathcal{N y m p h o p h i l u s ~}$ Taylor. The springs, as called by current researchers Túnel 4 and Túnel 8, are located at the foot of small hills in front of the Sierra la Cadena (Figure 1) and they belong to a system of several water bodies that have provided water to small settlements at the vicinity (Czaja et al., 2015). Both sites contain an abundance of shells, possibly including several new Cochliopidae species (Czaja, unpublished data). Only one of these species, Mexipyrgus viescaensis Czaja, Estrada-Rodríguez and Romero-Méndez, was described (Czaja et al., 2015). The spring sediments consist of small travertine pieces, shells, shell fragments (debris) and scant remnants of clay. Among the remains of aquatic vegetation, we found oogonia of Chara, seeds of Nymphaea(?) and endocarps of sedges (Cladium jamaicense Crantz and Schoenoplectus sp.). Microbialite (stromatolite) structures in form of tufa limestone were observed in both springs.

The aim of the present study is to describe the new species of Pyrgulopsis and to show its similarities, differences and possible phylogenetic relation to related living organisms from Cuatrociénegas valley.

\section{Material and method}

Specimens of the new species were collected from two recently dried-up springs near the town of $\mathrm{Vi}$ esca, Coahuila (Figure 1; spring Túnel 4: 25 20' 20" N, $102^{\circ} 52^{\prime} 32^{\prime \prime} \mathrm{W}$; spring Túnel 8: 25²0' $23^{\prime \prime} \mathrm{N}, 102^{\circ} 54^{\prime}$ 29" W). Shells of Túnel 4 were collected from a cut inside the spring approx. 50 $\mathrm{cm}$ below the surface. Shells of Túnel 8 spring were collected directly from a narrow fissure, approx. $60-70 \mathrm{~cm}$ below the surface. The section is approximately $2 \mathrm{~m}$ thick and contains unconsolidated sediments, small travertine pieces and shell debris. Empty shells of the extant species of Pyrgulopsis minckleyi from Poza Becerra and Poza Azul in Cuatrociénegas (about $200 \mathrm{~km}$ away from Viesca) were collected during the summer of 2015 directly from sediments at the bottom of these springs.

The sediments were screened through $0.5 \mathrm{~mm}$ and $0.3 \mathrm{~mm}$ sieves. The shells were photographed with a Zeiss AxioCam ERc5s microscope-camera. Morphometric variables of the shells (shell height and width, aperture height and width) were measured using a Neubauer Chamber Cell Counting Hemocytometer. Shells whorls were counted according to the method of Pilsbry (1939).

The Late Holocene age of the superficial deposits 


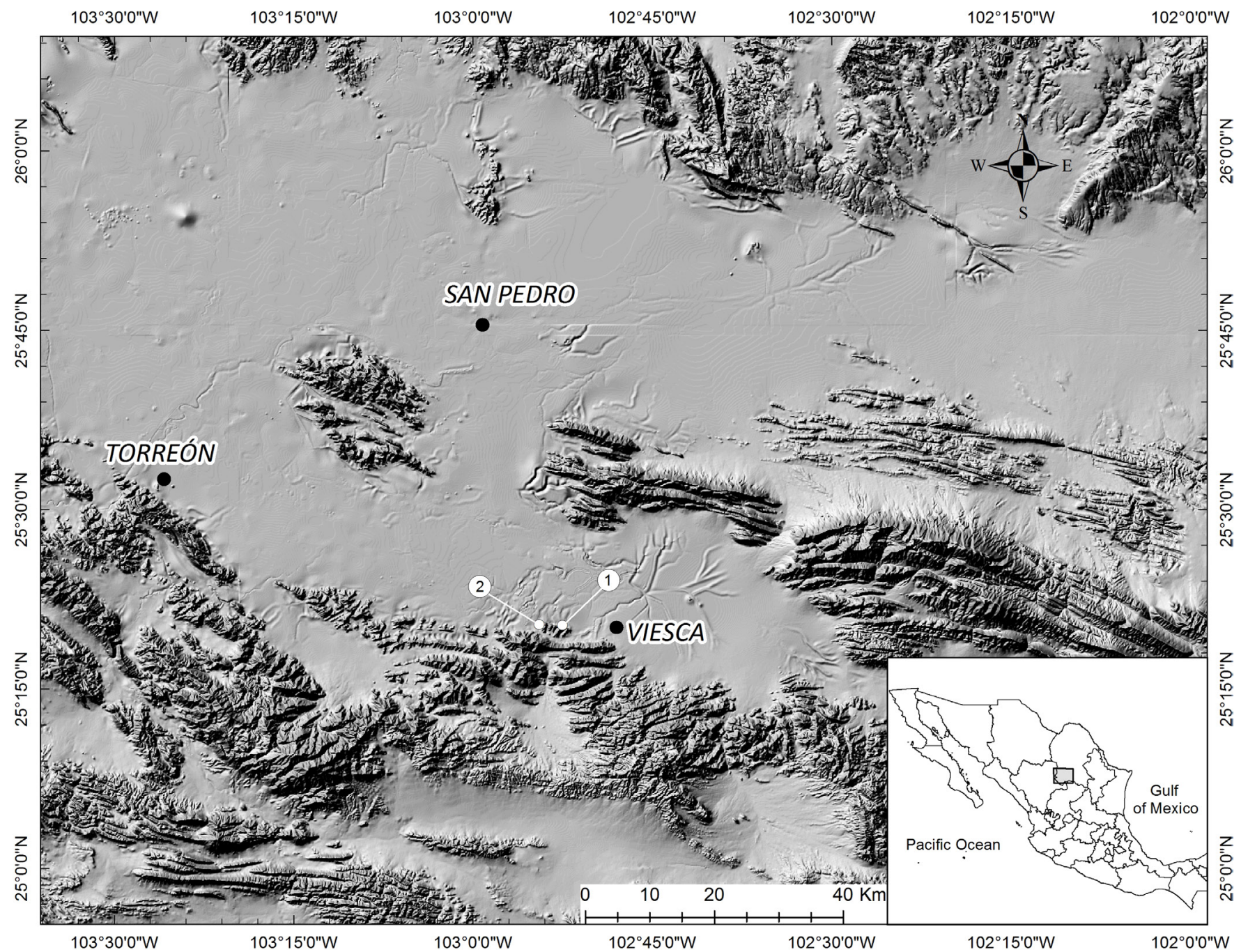

Figure 1 Map of the study area with localization of the springs of Viesca. $1=$ Spring Túnel 4, 2= Spring Túnel 8.

from the springs atViesca is confirmed by several reports and photographs which document the desiccation of the springs during the drought of 1958-1959 (Czaja et al., 2015). According to Late Pleistocene megafauna bone records at the base of the springs (Dr. J. Quiroz, personal data), we estimate the tafocoenosis age for the new species of Pyrgulopsis not older than Late Pleistocene, very likely latest Pleistocene/Early Holocene. This is supported also by the excellent conservation of the shells which retain often their original shell coloring (Figure 2a-d; Figure 3a, b, f). Shells of mollusks of Late Pleistocene sites of the region are always white bleached (Czaja et al., 2014a) (This dating is preliminary, radiometric dating of the shells, planned for our next project in Viesca, will give the exact age).

The material is deposited at the Malacological Collection of the Faculty of Biological Science of the Juarez State University of Durango (UJMC).

\section{Results}

\subsection{SYSTEMATICS}

Family Hydrobiidae Troschel, 1857

Subfamily Nymphophilinae Taylor, 1966 Genus Pyrgulopsis Call and Pilsbry, 1886 
Type species: Pyrgula nevadensis Stearns, 1883, by original designation.

Pyrgulopsis paleominckleyi Czaja, Estrada-Rodríguez, Romero-Méndez and Orona-Espino sp. nov. (Figures 2a, b)

Types. Holotype, UJMC-270, Túnel 8 Spring, narrow fissure, approx. $70 \mathrm{~cm}$ below the surface inside the spring, layer approx. $70-60 \mathrm{~cm}$ below the surface, Viesca, Coahuila, Mexico, 25 20' 23" N, $102^{\circ} 54^{\prime} 29^{\prime \prime}$ W. Paratypes from the same lot, UJMC-271-280a, 103 specimens.

Etymology. The name with the prefix "paleo" suggests that the sub-fossil species is probably an ancestor of the extant species P. minckleyi from $\mathrm{Cu}$ atrociénegas, Coahuila.

Diagnosis. A small species of Pyrgulopsis, narrowly umbilicate, ovate-conic to trochiform shell with penultimate and ultimate whorls flattened. The new species is differentiated from closely related P. minckleyi in having small size and strong, often bulb-like shoulder; a smaller spire-angle and the lack of a strong spiral keel.

Description. Morphologically quite variable species, shell small to medium sized, ovate-conic to trochiform (Figure 2a-e, f, l). The spire is moderately high, the base rounded, narrowly umbilicate, perforation almost complete covered by the columellar lip. The sutures are shallow. The aperture is oval in outline, longer than wide, adnate to or slightly separated from the penultimate whorl, angled adapically, rounded abapically. The aperture in lateral profile lies at an angle of about $15-25^{\circ}$ (some specimens up to $35^{\circ}$, Figure $2 \mathrm{j}$ ) to the coiling axis. Peristome complete, inner lip slightly thickened, outer lip thin. Protoconch flattened, near smooth, often eroded. Protoconch-teleoconch transition is in some specimens visible as a subtle change in sculpture (fine growth lines after 1.25 whorls, Figure 2n). Shells with 4.00 to 4.50 whorls, apical whorls rounded, following two whorls flattened to slightly convex giving the shell a trochoid shape (Figure 2e, f). Teleoconch whorls with coarses, wavies, and transverse growth lines. Ultimate and penultimate whorl frequently with a strong, bulb-like shoulder (Figure 2c, d) which in some specimens may be converted to a wing-like keel or collar (Figure 2i, j, o). The shells are whitish beige to light gray. Operculum not preserved. Shell measurements and whorl counts are given in Table 1.

Distribution. Pyrgulopsis paleominckleyi is endemic to Túnel 8 Spring at Viesca, Coahuila, Mexico.

Remarks. Some specimens of $P$. paleominckleyi show wing-like shoulders on the body-whorls that have never been observed among fossil or extant members of the genus. There are smooth transitions between shells with weak shoulders and shells with wing-like shoulder or collar; therefore, we consider that all specimens belong to one single species. Many other species in Viesca also have a strong shoulder, often with knobs or spines (Czaja et al., 2015). We suppose that such feature could serve to reinforce the wall of the shell as adaptation against predation. This bulb-like shoulder allows a clear identification of this new species. There are many other extant species of Pyrgulopsis with shoulders but these are never bulb- or wing-like. Furthermore, these shells are mostly globose and larger. Only $P$. archimedis (Oregon, United States) and $P$. nevadensis (Nevada, United States) have strong keeled shells but these are basal carinae and the shells have a completely different shape. Most similar to our new species is undoubtedly $P$. minckleyi from Cuatrociénegas, Coahuila, and the general similarity is evident (Figure 2g, h, k, 1). But the shells of this extant species are considerably greater (up to $8 \mathrm{~mm}$ ), stronger and more triangular in shape. Besides, most specimens possess a strong spiral keel which reaches up to the aperture (Figure $2 \mathrm{k})$.

Pyrgulopsis paleoacarinatus Czaja, Estrada-Rodríguez, Romero-Méndez and Orona-Espino sp. nov.

Types. Holotype, UJMC-281, Túnel 4 spring, cut inside the spring, layer approx. $50 \mathrm{~cm}$ below the surface, Viesca, Coahuila, Mexico, 25²0' $20^{\prime \prime} \mathrm{N}, 102^{\circ} 52^{\prime} 32^{\prime \prime} \mathrm{W}$. Paratypes from the same lot, UJMC-282-289a, 42 specimens and from the Túnel 8 spring, 1 specimen. 


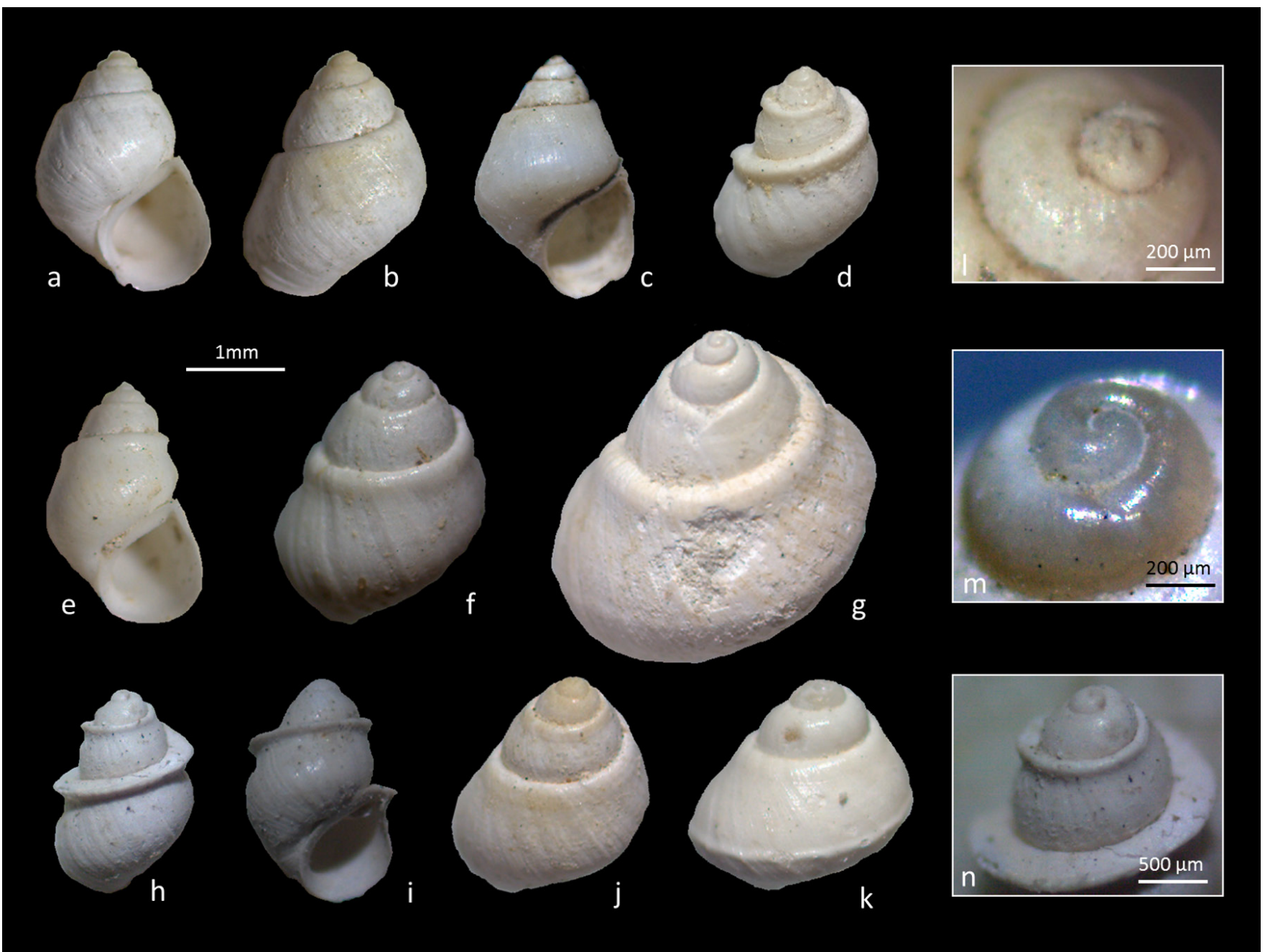

Figure 2 Shells of Pyrgulopsis paleominckleyi sp. nov. from Viesca, Coahuila and Pyrgulopsis minckleyi Taylor from Poza Becerra, Cuatrociénegas, Coahuila. P. paleominckleyi sp. nov.: (a, b) holotype (UJMC-270); (c) paratype 1 (UJMC-271); (d) paratype 2 (UJMC-272); (e) paratype 3 (UJMC-273); (f) paratype 4 (UJMC-274); (h) paratype 5 (UJMC-275); (i) paratype 6 (UJMC-276); (j) paratype 7 (UJMC-277); (I) paratype 1, protoconch view; (n) paratype 5, details of the wing-like shoulders. Pyrgulopsis minckleyi Taylor: (g) specimen from Poza de la Becerra; (k) small specimen from Poza de la Becerra; $(m)$ specimen from Poza Azul, protoconch view.

Etymology. The name with the prefix "paleo" suggests that the sub-recent species is a probably ancestor of the extant species $P$. acarinatus from $\mathrm{Cu}-$ atrociénegas, Coahuila.

Diagnosis. A small species of Pyrgulopsis, umbilicate, ovate-conic to elongate conic shell, it has moderately convex whorls. The new species is differentiated from closely related $P$. acarinatus in having significantly a smaller size and more elongate conic shell shape.

Description. Shell small to medium sized, ovate-conic to elongate conic. The spire is mod- erately high, the base rounded, umbilicate. The aperture is large and oval in outline, longer than wide, adnate to or - mostly- slightly separated from the penultimate whorl, angled adapically, rounded abapically. The aperture in lateral profile lies at an angle of about $5-10^{\circ}$ to the coiling axis. Protoconch flattened, near smooth. Protoconch-teleoconch transition is not visible. Shells with 3.75 to 4.50 whorls, apical whorls rounded, teleoconch whorls moderately convex, never shouldered, with coarse, wavy and transverse growth lines, on the bodywhorl-toward to the aperture weak ribs can 
Table 1. Whorl counts and measurements of shells of Pyrgulopsis paleominckleyi sp. nov. WN, total number of whorls; SH, shell height; SW, shell width; AH, aperture height; AW, aperture width. All measurements in millimeters.

\begin{tabular}{|c|c|c|c|c|c|}
\hline Specimen & $\mathbf{W N}$ & SH & SW & $\mathbf{A H}$ & $\mathbf{A W}$ \\
\hline P. paleominckleyi 1 (Holotype) & 4.25 & 2.74 & 1.83 & 1.52 & 1.33 \\
\hline P. paleominckleyi 2 & 4.50 & 2.68 & 1.77 & 1.50 & 1.04 \\
\hline P. paleominckleyi 3 & 4.00 & 2.82 & 1.92 & 1.40 & 1.28 \\
\hline P. paleominckleyi 4 & 4.25 & 2.93 & 1.84 & 1.48 & 1.37 \\
\hline P. paleominckleyi 5 & 4.25 & 2.24 & 1.45 & 1.38 & 1.02 \\
\hline P. paleominckleyi 6 & 4.00 & 2.21 & 1.43 & 1.24 & 0.94 \\
\hline P.paleominckleyi 7 & 4.00 & 2.19 & 1.42 & 1.21 & 0.97 \\
\hline P. paleominckleyi 8 & 4.25 & 2.97 & 1.96 & 1.69 & 1.38 \\
\hline P. paleominckleyi 9 & 4.25 & 2.25 & 1.62 & 1.22 & 1.02 \\
\hline P. paleominckleyi 10 & 4.25 & 2.95 & 1.94 & 1.52 & 1.38 \\
\hline P. paleominckleyi 11 & 4.25 & 2.34 & 1.42 & 1.22 & 1.01 \\
\hline P. paleominckleyi 12 & 4.50 & 2.91 & 1.86 & 1.58 & 1.27 \\
\hline P. paleominckleyi 13 & 4.00 & 2.51 & 1.68 & 1.23 & 1.09 \\
\hline P. paleominckleyi 14 & 4.25 & 2.26 & 1.59 & 1.25 & 0.98 \\
\hline P. paleominckleyi 15 & 4.25 & 2.39 & 1.58 & 1.34 & 1.16 \\
\hline mean & 4.22 & 2.56 & 1.69 & 1.39 & 1.15 \\
\hline standard deviation & 0.16 & 0.31 & 0.2 & 0.16 & 0.17 \\
\hline
\end{tabular}

be developed. (Figure 3b, e). The last whorl larger, it makes up $50-65$ per cent of the total shell height. The shells are whitish beige to light gray. Operculum not preserved. Shell measurements and whorl counts are given in Table 2.

Distribution. Pyrgulopsis paleoacarinatus is endemic to Túnel 4 and Túnel 8 springs at Viesca, Coahuila, Mexico.

Remarks. $P$. acarinatus is very rare in Cuatrociénegas and we could not collect specimens for direct comparison. But according to the description and illustrations of Hershler (1985) we conclude that our new species from Viesca differs from $P$. acarinatus only in its small size, more prolonged shell shape and stronger pronounced growth lines on the last whorl (Figure 3b, e). These differences and the geographical distance between Cuatrociénegas and Viesca suggest that $P$. paleoacarinatus is a distinct species and not an allopatric morphotype of $P$. acarinatus.

\section{Discussion}

For large, carinate and trochoid shells from the springs of Cuatrociénegas valley established Taylor (1966) the subfamily Nymphophilinae. He included in this subfamily only one species: Nymphophilus minckleyi. For Taylor these shells were "... remarkably large for the family... most un-hydrobiid in general appearance... reminds one more of the marine Trochidae". Hershler (1985) later added to the same valley Nymphophilus acarinatus, a second smaller congener with rounded whorls. The genus was conchologically well characterized; however, molecular genetic studies of Liu and Hershler (2005) showed that Nymphophilus is little differentiated from Pyrgulopsis and should therefore be treated as a synonym. These authors suggest that the unusual strong and large shells of Nymphophilus (sensu 


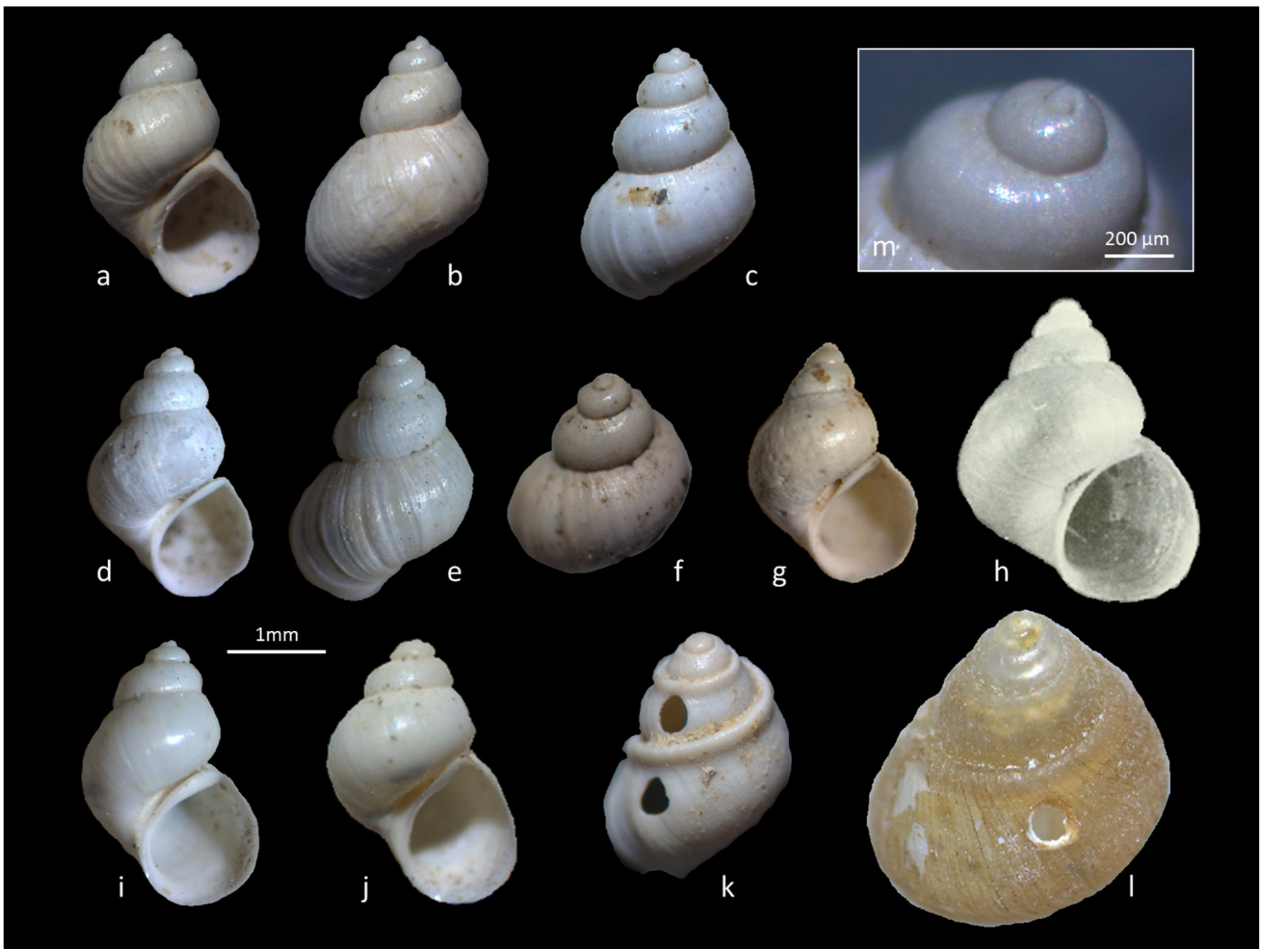

Figure 3 Shells of Pyrgulopsis paleoacarinatus sp. nov. from Viesca, Coahuila, Pyrgulopsis acarinatus Taylor from Locality 113 in Cuatrociénegas, Coahuila (from Hershler, 1985, Figure. 9, reprinted with author's permission), Pyrgulopsis paleominckleyi sp. nov. from Viesca and P. minckleyi from Poza Azul in Cuatrociénegas. P. paleoacarinatus sp. nov.: (a, b) holotype (UJMC-281); (c) paratype 1 (UJMC-282); (d-e) paratype 2 (UJMC-283); (f) paratype 3 (UJMC-284); (g) paratype 4 (UJMC-285); (i) paratype 5 (UJMC-286); (j) paratype 6 (UJMC-287); (m) protoconch view (holotype). P. acarinatus Taylor: (h) specimen from Locality 113 in Cuatrociénegas. P. paleominckleyi sp. nov.: (k) specimen (UJMC-288) with double holes on the ab-apertural side on the shell. $P$. minckleyi Taylor: (I) specimen with a hole on the ab-apertural side on the shell.

lato)"...may be viewed as one of the multiple independent radiations in thermal ecosystems that occurred within the evolutionary history of Pyrgulopsis..." and added that "...these separate clades represents a parallel evolutionary response to the snail-eating fishes and other predators (e.g., crayfish) which commonly live in these habitats" (Liu and Hershler, 2005, p. 293).

More recent studies on fishes and snails of Cuatrociénegas confirm that the mentioned unusual shell features result from a strong fish predation (Chaves-Campos et al., 2012; Covich, 2010; John- son et al., 2007). Czaja et al. (2015) interpreted small holes in many shells from Viesca and Cuatrociénegas as perforations of a fish predator. Such holes were described for the first time by Rasser and Covich (2014) from Miocene Lake Steinheim, Germany. Indeed, in Pyrgulopsis sp. nov. specimen horizons, we found numerous pharyngeal teeth, vertebrae, and scales of fishes which were probably cichlids. Eleven shells $(=10 \%)$ of P. paleominckleyi sp. nov. were perforated (Figure 3k) and several repaired shell injuries were observed. Such traces 
Table 2. Whorl counts and measurements of shells of Pyrgulopsis paleoacarinatus sp. nov. WN, total number of whorls; SH, shell height; SW, shell width; AH, aperture height; AW, aperture width. All measurements in millimeters.

\begin{tabular}{|c|c|c|c|c|c|}
\hline Specimen & $\mathbf{W N}$ & SH & SW & AH & $\mathbf{A W}$ \\
\hline P. paleoacarinatus 1 (Holotype) & 4.25 & 2.62 & 1.81 & 1.42 & 1.22 \\
\hline P. paleoacarinatus 2 & 4.25 & 2.76 & 1.81 & 1.38 & 1.19 \\
\hline P. paleoacarinatus 3 & 4.00 & 2.63 & 1.88 & 1.52 & 1.15 \\
\hline P. paleoacarinatus 4 & 4.25 & 2.72 & 1.99 & 1.58 & 1.24 \\
\hline P. paleoacarinatus 5 & 4.25 & 2.75 & 1.92 & 1.28 & 1.19 \\
\hline P. paleoacarinatus 6 & 4.50 & 2.98 & 1.96 & 1.53 & 1.23 \\
\hline P. paleoacarinatus 7 & 4.50 & 2.62 & 1.74 & 1.46 & 1.14 \\
\hline P. paleoacarinatus 8 & 4.25 & 2.49 & 1.59 & 1.22 & 1.03 \\
\hline P. paleoacarinatus 9 & 4.50 & 3.08 & 2.07 & 1.62 & 1.38 \\
\hline P. paleoacarinatus 10 & 4.50 & 2.99 & 1.98 & 1.51 & 1.28 \\
\hline P. paleoacarinatus 11 & 4.00 & 2.23 & 1.39 & 1.22 & 0.97 \\
\hline P. paleoacarinatus 12 & 3.75 & 2.12 & 1.52 & 1.14 & 0.99 \\
\hline P. paleoacarinatus 13 & 4.00 & 2.74 & 1.61 & 1.32 & 1.22 \\
\hline P. paleoacarinatus 14 & 3.75 & 2.17 & 1.48 & 1.13 & 0.98 \\
\hline P. paleoacarinatus 15 & 4.25 & 2.49 & 1.62 & 1.33 & 1.17 \\
\hline mean & 4.20 & 2.63 & 1.76 & 1.38 & 1.16 \\
\hline standard deviation & 0.25 & 0.29 & 0.21 & 0.16 & 0.12 \\
\hline
\end{tabular}

were interpreted by Lindström and Peel (2005) as unsuccessful predatory attacks. Two specimens $(=$ $5 \%$ of $P$. paleoacarinatus sp. nov. were perforated and one shows a repaired shell. This confirms indirectly the mentioned presumption of Liu and Hershler (2005) about the parallel evolution between fishes and snails also for Viesca and is, at the same time, a good example of how biology and paleontology can be mutually supportive.

Shells of the described two species of Pyrgulopsis are present in the section of Viesca only in a thin layer and we do not know why they became extinct. Our new snails from Viesca were apparently exposed to predation not that much time as the extant species from Cuatrociénegas. That would explain why their general appearance is not so "un-hydrobiid" (Taylor, 1966) as the shells of Cuatrociénegas are. Our hypothesis is that P. paleominckleyi and P. paleoacarinatus are sister species or direct precursors of two extant endemic species of Pyrgulopsis from Cuatrociénegas. It has its main justification in the similar shell characters. But also other considerations point to the same direction. It is certainly no coincidence or convergence that in Viesca we did not found one - as well as in Cuatrociénegas-but two species and that they resemble precisely shells of the "separate clade" of Pyrgulopsis (= Nymphophilus sensu lato). Convergences were indeed frequently observed in hydrobiid snails but a "double convergence" would be highly unlikely. Noteworthy, and surely also no coincidence, there is another similarity: One of the two Pyrgulopsis extant species from Cuatrociénegas $-P$. minckleyi- show high shell variability, while $P$. acarinatus produce very uniform shells. Similarly, in Viesca, high shell variability only in P. paleominckleyi could be observed. Viesca region has a remarkable similarity to the malacofauna of Cuatrociénegas, where almost all genera (Mexipyrgus, Paludiscala, Coahuilix, futurnia) and species of snails that today 
are endemic to the Cuatrociénegas Valley were confirmed (Czaja et al., 2015; unpublished data). Given this fact, is not surprising that both localities contain also narrowly related species of the genus Pyrgulopsis.

In summary, the aforementioned ideas suggest that both sub-fossil species from Viesca are direct precursors, rather than sister species. We suspect the "separate clade" of Pyrgulopsis evolved during Pleistocene or earlier in Viesca and afterward (in early Holocene?) the snails were introduced to $\mathrm{Cu}-$ atrociénegas possibly by avian transport. The distribution of small shells by birds is very common (Wesselingh et al., 1999) and has long been known in the literature (Darwin, 1859). Paleontological investigations (excavations) in Cuatrociénegas can provide the final proof that $P$. paleominckleyi and $P$. paleoacarinatus are direct precursors of two extant endemic species of Pyrgulopsis. Future work on sub-fossil shells in both localities will allow us to know more on the evolutionary path of the genus Pyrgulopsis from northern Mexico.

\section{Acknowledgements}

We thank both Biol. Arturo H. González González, director of the Museo del Desierto in Saltillo, Coahuila, for permission to recollect soil samples of the dissected part of the Poza de la Becerra, Cuatrociénegas and Lic. Juan Carlos Ibarra Flores of the Área de Protección de Flora y Fauna Cuatrociénegas, for permission to recollect soil samples of the Poza Azul in Cuatrociénegas. We thank an anonymous reviewer for its constructive comments. A special thank you goes to Allen Kosinski, New Jersey, USA, for his assistance in the revision of the text in English.

\section{References}

Chaves-Campos, J., Coghill, L.M., Al-Salamah, M.A., DeWitt, T.J., Johnson, S.G., 2012, Field heritabilities and lack of correlation of snail shell form and anti-predator function estimated using Bayesian and maximum likelihood methods: Evolutionary Ecology Research, 14, 743-755.

Covich, A.P., 2010, Winning the biodiversity arms race among freshwater gastropods: competition and coexistence through shell variability and predator avoidance: Hydrobiologia, 653, 191-215.

Czaja, A., Estrada-Rodríguez, J.L., RomeroMéndez, U., 2014a, Fresh water mollusks of the Valley of Sobaco, Coahuila, Northeastern Mexico - a subfossil ecosystem similar to Cuatrociénegas: Boletín de la Sociedad Geológica Mexicana, 66 (3), 459-469.

Czaja, A., Palacios-Fest, M.R., EstradaRodríguez, J.L., Romero-Méndez, U., AlbaAvila, J.A., 2014b, Inland Dunes mollusks fauna from the Paleolake Irritila in the Comarca Lagunera, Coahuila, Northern Mexico: Boletín de la Sociedad Geológica Mexicana, 66 (3), 541-551.

Czaja, A., Estrada-Rodríguez, J.L., RomeroMéndez, U., 2015, A new species of the genus Mexipyrgus Taylor, 1966 (Caenogastropoda: Truncatelloidea: Cochliopidae) from late Holocene spring deposits in Viesca, Coahuila, Mexico: The Nautilus, 129, 163-168.

Darwin, C., 1859, The origin of the species: Oxford University Press, Oxford (1998), 439 p.

Henderson, J., 1935, Fossil non-marine Mollusca of North America: Geological Society of America Special Papers, 3, 1-313.

Hershler, R., 1985, Systematic revision of the Hydrobiidae (Gastropoda: Rissoacea) of the CuatroCienegas Basin, Coahuila, Mexico: Malacologia, 26 (1-2), 31-123.

Hershler, R., Liu, H.-P., Howard, J., 2014, Springsnails: a new conservation focus in western North America: BioScience, 64, 693-700.

Hershler, R., Liu, H-P., Stevens, L.E., 2016, A new springsnail (Hydrobiidae: Pyrgulopsis) from the lower Colorado River Basin, 
northwestern Arizona: Western North American Naturalist, 76 (1), 72-81.

Hershler, R., Sada, D., 2002, Biogeography of Great Basin aquatic snails of the genus Pyrgulopsis, in Hershler, R., Madsen, D.B., Currey, D.R. (eds.), Great Basin aquatic systems history: Smithsonian, Smithsonian Contributions to the Earth Sciences, 33, 255-276.

Hurt, G.R., 2004, Genetic divergence, population structure and historical demography of are springsnails (Pyrgulopsis) in the lower Colorado River basin: Molecular Ecology, $13(5): 1173-1187$.

Johnson, S.G., Hulsey, C.D., García de León, F.J., 2007, Spatial mosaic evolution of snail defensive traits: BMC Evolutionary Biology, 7, doi:10.1186/1471-2148-7-50

Lindström, A., Peel, J.S., 2005, Repaired in juries and shell form in some Paleozoic pleurotomarioid gastropods: Acta Palaeontologica Polonica, 50, 697-704.
Liu, H.-P., Hershler, R., 2005, Molecular systematics and radiation of western North American nymphophiline gastropods: Molecular Phylogenetics and Evolution, 34, 284-298.

Pilsbry, H.A., 1939, Land Mollusca of North America: Academy of Natural Sciences of Philadelphia, Monograph 3, 1, 547 p.

Rasser, W.M., Govich, A.P., 2014, Predation on freshwater snails in Miocene Lake Steinheim: a trigger for intralacustrine evolution?: Lethaia, 47 (4), 524-532.

Taylor, D.W. 1966, A remarkable snail fauna from Coahuila, Mexico: The Veliger, 9, 152-228.

Wesselingh, F.P., Cadée, G.C., Renema, W., 1999, Flying high: on the airborne dispersal of aquatic organisms as illustrated by the distribution histories of the gastropod genera: Geologie en Mijnbouw, 78, 165-174. 